\title{
The impact of culture-related factors on good governance in Greek family businesses in South Africa
}

\author{
C. Adendorff \\ Nelson Mandela Metropolitan University Business School, \\ Port Elizabeth, Republic of South Africa \\ C. Boshoff* \\ Department of Business Management, University of Stellenbosch, \\ Private Bag X1, Stellenbosch 7600, Republic of South Africa \\ cboshoff@sun.ac.za
}

Received May 2010

\begin{abstract}
The size of the family business component of the South African economy suggests that it is the predominant way of doing business in South Africa. A large proportion of these family businesses are Greek-owned. More importantly it is estimated that approximately $95 \%$ of all Greek businesses in South Africa can be classified as family businesses. The sustainability of Greek family businesses requires that they maintain good governance practices that are both economically and environmentally acceptable to all stakeholders. It also requires that the next generation of Greek entrepreneurs effectively balance good governance of their businesses with their family commitments.
\end{abstract}

The primary objective of this study was to identify and explore the internal, culturally-related factors that influence good governance to ensure the survival, growth and sustainability of Greek family businesses in South Africa. A theoretical model of good governance factors was proposed and tested using Structural Equation Modelling.

\begin{abstract}
The study found that perceived good governance in a South African Greek family business context needs to be managed in terms of three factors, namely risk control, the internal regulatory environment and the protection of the stakeholders' interest. The study found that needs alignment, cultural needs alignment, vision and ethnic entrepreneurial growth all impact directly or indirectly on perceived good governance in South African Greek family businesses.
\end{abstract}

*To whom all correspondence should be addressed.

\section{Introduction}

Internationally, the overwhelming majority of family businesses are small or medium-sized (Bjurren \& Sund, 2000:2; Goldberg, 1991:2; Hume, 1991:3; Maas, 1999; Serrano, 2000:23). Even the most conservative estimates put the proportion of all worldwide business enterprises owned or managed by families at between $65 \%$ and $90 \%$ (Gersick, Davis, McCollon \& Lansberg, 1997:2; Sharma, Chrisman \& Chua, 1997:233; Van der Merwe, 1999; Zimmerer \& Scaborough, 2002:19; Venter, 2003:32). In several countries, family businesses form the majority of all businesses. The figures (supplied by IFERA, 2003) for various countries are: France $(60 \%)$, Germany $(60 \%)$, the Netherlands (74\%), Portugal (70\%), Belgium (70\%), United Kingdom $(70 \%)$, Spain $(75 \%)$, Sweden $(79 \%)$, Finland $(80 \%)$, Greece $(80 \%)$, Cyprus $(80 \%)$, Italy $(93 \%)$, Australia $(75 \%)$ and the USA $(95 \%)$.

The economic importance of family businesses for the economies of both the developed world and developing countries such as South Africa are well documented (Steier, 2001; Venter, 2003; Adendorff, Boshoff \& Venter, 2008). Family businesses are, however, one of the most unique, complex, and dynamic systems in our modern-day society. The blending of two inherently different realms - the performance-based world of business and the emotion-based domain of the family - creates a system potentially fraught with confusion and conflict (McCann, Hammon, Keyt \& Fujiuchi, 2004).

The literature on family business provides ample evidence of the difficulty of perpetrating the enterprise beyond the second and third generation. The Greek saying that "The first generation makes the money, the second generation spends it and the third generation loses it", is almost as universal as the law of gravity. A very small percentage of family businesses survive the 'cousins consortium' stage and several authors have suggested a direct link between the prosperity and survival of all business entities over the long term on the one hand and good governance on the other hand. Family businesses are not an exception (Adair, Brett, Lempereur, Okumura, Tinsley, \& Lytle, 1998).

The relative importance of the family in different societies varies across cultures, and therefore, it can be concluded that the definition of the term family business is culture-specific (Ng, 1999; Daily \& Dollinger, 1991; Sharma, 1997; 
Neubauer \& Lank, 1998). The field of international management often neglects specific aspects of culture in favour of a more easily defined (and less theoretically precise) parameter denoted by geopolitical boundaries (Hofstede, 2001, Adendorff et al., 2008) when discussing managerial practices.

It should be accepted that in order to sustain and enhance the considerable contribution of family business to national economic growth in general, a family business is fundamentally different from the other forms of private economic organisations (Maas, 1999; Venter, 2003). The key difference is that the affairs of a family business are closely and intricately intertwined with the personal financial affairs of the family and also with the power relationships, blood ties, emotional bonds and inheritance issues within that family (Astrachan \& Astrachan, 1993; Connolly \& Jay 1996:5; Sharma, Chrisman \& Chua, 1997:2; Venter, 2003).

The insistence of many stakeholders in the South African economy for good governance has led to the so-called "King Reports" (King, 2001; Institute of Directors of Southern Africa, 2002), the prominence of which has placed governance issues firmly in the public domain (Vaida, 2005). Of more importance is the fact that several authors have suggested (Neubauer \& Lank, 1998; Ward, 1995) and empirically proven (Neubauer \& Lank, 1998; Adendorff, et al., 2008) a direct link between the prosperity and survival of all business entities over the long term and good governance. As recently as 2007 , the international economic crisis that led to the widespread international recession has been attributed to poor corporate governance.

In the small business sector in general and the family business sector in particular, the link between longevity and good governance is complicated by two additional factors. The first is the failure to realise that the specific operating characteristics of a family business can be a source of persistent business problems, missed opportunities, and unnecessary risks, that could and should be avoided (Adendorff, Boshoff, Court \& Radloff, 2005). Failure by the members of a family business to acknowledge the unique characteristics of their business could similarly have severe and lasting adverse consequences on the business (Adendorff, Boshoff \& Venter, 2008). In order to allow a family business to make its rightful contribution to any country's economy, it must be acknowledged that its unique nature will impact on its corporate governance (Neubauer \& Lank, 1998) and thus, on its survival.

The second complicating factor is the reality that corporate governance cannot be "standardised" for all ethnic groupings that function in an economy (Hofstede, 2001). The way in which corporate governance is implemented has been shown to be affected by ethnic and cultural influences (Ward, 1995; Adendorff \& Boshoff, 2009).

Despite the acknowledgement by some authors that ethnic and cultural influences impact on family businesses (Ward, 1995), few (if any) studies have been carried out to explore the relationship between cultural influence in family businesses and its impact on corporate governance and thus, ultimately on their survival and contribution to national economic prosperity. Certainly, no empirical study has been done in South Africa to investigate the relationship between culture and corporate governance. This study specifically investigates the perceptions and attitudes of Greek family businesses towards corporate governance. A study of this nature is of particular importance if the economic influence of Greek families in the South African economy is considered. More than $80 \%$ of Spar outlets, for instance, are controlled by Greek families, as are $90 \%$ of the South African shipping supply industry's ship chandler's services. Fast-food outlets such as Spur and Debonair, and at retail level, Seven Eleven, Fruit and Veg, Famous Brands, and Pick 'n Pay, to name but a few, are dominated by Greek interests.

To summarise, given the relative importance of family businesses in South Africa in general, as well as the considerable influence of Greek family control in the South African economy in particular, the absence of empirical evidence on the relationship between cultural influences and good governance presents an important gap in the familybusiness literature. This study addresses this limitation by identifying the factors that influence good governance in Greek family businesses in South Africa. The basic underlying premise of the study is that once the factors that could enhance good governance have been identified, the effective management of governance may be implemented to ensure that these important business entities optimise their critically important contribution to the South African economy.

This paper reports on the third component of a comprehensive model to explain good governance in Greek family businesses. The model consisted of three components (in essence three sets of independent variables) namely planning (results reported in Adendorff et al., 2005), family harmony (results reported in Adendorff et al., 2008) and culture-related variables (this paper). Due to the size of the proposed model relative to the number of parameters to be estimated, the sample size was insufficient to subject the complete model to a structural equation assessment (Hair, Black, Babin, Anderson \& Tatham, 2005: 741). The model was then divided onto the said three components and the results of each sub-component reported separately. ${ }^{1}$

\section{The Greek culture}

Research undertaken in the area of cross-cultural management (Hofstede, 2001; Dimitriades, 2004) and ethnocentrically-based behaviours and perceptions in organisations, have tended to concentrate on the identification of differences between nations and the categorization of behaviours (Adendorff \& Boshoff, 2009).

Some researchers have provided critical reflections and cross-cultural research approaches about the inclusion of cultural diversity in management theory (Hofstede, 2001, Dimitriades, 2004; Adendorff, 2004). Others have examined cultural diversity in organisations broadly, with some focusing on the social and economic influences in multicultural workforces (e.g. Cox \& Blake, 1991;

\footnotetext{
${ }^{1}$ All the data were collected in a single survey.
} 
Hampden-Turner \& Trompenaars, 2000; Kalantzis \& Cope, 1992).

Many social scientists who have studied the role of culture in a business context have relied on the work of Hofstede (2001). Over time, additional dimensions of culture were added to Hofstede's original four. As a result more comprehensive value measures have been developed. Others have researched ways to conceptualise and measure culture, such as the assessment of social axioms. Others have added eco-social indicators that permitted a comparison of different cultural systems. As Triandis (2000) has pointed out, these new approaches have allowed researchers to better understand cultural variation and are being utilised to explore ways in which a person's cultural background may be scientifically linked to his or her social and commercial behaviour. The growing appreciation of the role of culture in organisational behaviour will enhance our understanding of good governance of both the family and the business.

The impact and influence of Greek family interests in South Africa are often underestimated, because they are not very vocal or prominent and often deliberately avoid the limelight (Adendorff et al., 2005). In fact, it can be concluded that the profitability and growth of Greek family businesses have a substantial impact on the South African economy as a whole. Yet these family firms are strongly influenced by their cultural norms.

Since a broad and complete overview of "culture" is beyond the scope of this study, the impact that Greek culture exerts on how South African Greek family businesses govern their families and businesses will be explored in this study. The South African Greek culture is quite distinct from that of Greece where culture progressed normally and evolved with the passing of time (Koliopoulos \& Veremis, 2002). The South African Greek culture on the other hand, as transplanted by the earlier immigrants, did not change much over the years. In the preservation of the original culture, there was an assertion of nationality and Greekness by the earlier immigrants. Especially for the older generations in South Africa, any concession to progress, any concession to change, or any deviation from the cultural patterns handed down by tradition would be a concession to "Africanism" (Mantzaris, 2000). In this way it can be said that Greeks in South Africa represented a conservative element, by retaining aspects of rural culture, such as family organisation, which, according to Koliopoulos and Veremis (2002), have even changed in Greece itself.

Despite many influences that could have reduced the South African Greek culture effect, Mantzaris (1978) and Spiro (2003) are of the opinion that the family has remained the strongest institution among South African Greeks. It is not only the main agent of socialisation, but is also the chief educational preserver of Greek ideals and the Greek way of life. An examination of the South African Greek family provides the opportunity to view more closely the moulding of the personality of its younger members, the transmission of the South African Greek culture, and the changing behavioural patterns through the generations (Mantzaris, 2000).
Davis (2001), Lansberg (1999), Ward (1997) and Neubauer \& Lank (1998) are all of the opinion that the governance of a family business is more complicated than for non-family owned businesses because of the central role played by the family. They also point out that in family businesses (where ownership is controlled by a single family) the lack of effective governance is a major cause of organisational problems. One of the most formidable obstacles to the stability, growth, and success of the family business is the issue of governance. To build upon and to remain a family business, the ultimate management challenge is to ensure good governance. Because of the important role Greek family businesses play in the South African economy, ensuring perceived good governance is of the utmost importance for the survival, growth, and the future prosperity of this very important component of the South African economy (Adendorff et al., 2005).

\section{The problem statement}

As it is a significant component of the South Africa economy, extensive debate, analysis and attention centred on family businesses would be expected. The truth is that this sector of the economy has been largely overlooked and ignored by South African academics and economic commentators alike. Against this background, the research problem investigated in this study was to assess the direct and indirect impact of culture-related factors in influencing perceived good corporate governance practices in Greek family businesses in South Africa.

In order to address the research problem, the following objectives were formulated:

- to identify the culture-related factors (variables) that impact on good governance in Greek family-owned businesses in South Africa;

- to construct a theoretical model that will describe the relationships between the identified culture-related variables and perceived good governance; and

- to empirically test the proposed theoretical model among Greek family members in South Africa.

In the theoretical model that forms the basis of this study, perceived good corporate governance is the dependent variable. The outcome of the study will hopefully, be a set of guidelines that can assist Greek families in their efforts to ensure good corporate governance in their family businesses, thereby ensuring their long-term survival, growth and profitability.

\section{The cultural related factors that influence perceived good governance}

The factors related to culture that could, according to the literature, directly influence perceived good governance and investigated in this study are: Needs and Cultural Values Alignment, Vision and Ethnic Entrepreneurial Growth. The influence of Needs and Cultural Values Alignment as an antecedent to Vision and Ethnic Entrepreneurial Growth, is also considered. 


\section{Needs and cultural values alignment and good governance}

A human value can be described is a preference of one mode of behaviour over another mode of behaviour. The relationship between values and culture is not onedirectional, however. Not only are values diverse when different cultural groups are compared, but values are learned behaviour strongly influenced by cultural norms (De Mooij, 1997). According to Zabkar and Brenic and (2001), values have cognitive, affective and behavioural components. In a business context, according to Morgan and Hunt (1994), shared values in business relationships refer to the extent to which stakeholders share common beliefs about visions, goals, growth, policies, and behaviours. More importantly, shared values are strong predictors of both relationship commitment and trust.

Not only are values important, but the role of the family itself cannot be ignored in the development of the entrepreneurship process of family businesses (Maas, 1999). According to Craig and Lindsay (2002), the role of the family is often to critically review prevailing business practices and activities, and to assess whether they place at risk important issues such as family traditions, culture, values, and assets. Many organisational theorists believe that the idea that efficiency considerations and bureaucratic rationality should predominate in the family business ignore how the involvement of the founder/current owner(s) influence managerial behaviour (Lansberg, 1988). In short, in family business, the cultural values of the family ownership and the management of the business are inextricably intertwined (Hoy \& Verser, 1994; Neubauer \& Lank, 1998).

This close link between family values and business decision-making often results in a "blurring" which impact on the family decision-making process (Neubauer \& Lank, 1998). As could be expected family businesses that have survived for several generations develop their own traditions, values, and customs that are, overtime, reflected in their administration and business strategies (McWhinney, 1988). As a result, family business cultures may become resistant to change (Gersick et al., 1997). An important reason for this resistance to change, according to Dyer (1994), is the role that emotions often play in family decision-making. These emotional considerations are seldom a consideration in non-family businesses. The tensions created by emotional considerations are typically strong "emotional attachments" to the tradition, culture, values, and the assets of family business. Family members often deal with this potential threat by restoring the status quo (Aldefer, 1988), that is, resisting change.

Several studies have highlighted that governance in family businesses can be influenced by the extent to which the personal needs and career interests of family members are aligned with the opportunities offered by the family business (Kaye, 1991; Neubauer \& Lank, 1998; Shen \& Conella, 2002). In other words, family business members who put family needs ahead of business needs are more likely to remain involved with the business (Muske, 2002).
Muske (2002) believes that, over time governance issues in family businesses start reflecting the family-way of doing things. Family business governance then becomes a confluence of the two dominant stakeholders - and indeed, sometimes a compromise - between the family's personal value system and the business's requirements. This synthesis may reflect all the critical steps in organisational development, from the early delegation process of managerial activities to the development of a managerial style to the involvement of the family members in management to the succession process and eventually coownership by third parties (Gersick et al., 1997).

Several authors, including Gopalkrishnan and Shapiro (2000), have demonstrated that ethnic entrepreneurs differ in their cultural orientation. Not all entrepreneurs hold the values of the abrasive, competitive, individualistic, and selfmade entrepreneur idolised by the typical Westerner dear. Moreover, the individual's cultural ties and personal cultural orientation, of which identity is one, guide many ethnic entrepreneurs to not focus solely on profitability. These and other cultural explanations have several implications for ethnic competition in an increasingly globalised world.

Based on this preview, the following three hypotheses need to be considered:

$\mathrm{H}^{1}$ : There is a positive relationship between needs and cultural values alignment and perceived good governance.

$\mathrm{H}^{2} \quad$ There is a positive relationship between needs and cultural values alignment and vision.

$\mathrm{H}^{3}$ : There is a positive relationship between needs and cultural values alignment and ethnic entrepreneurial growth.

\section{Vision and good governance}

The family business is typically managed with the intention of shaping and pursuing a vision of the business that is potentially sustainable across several generations of the family (Chua, Chrisman \& Sharma, 1999). A family business' vision is typically shaped and pursued by a dominant coalition controlled by a family member, the managing group or the original founder. This vision may serve only the interests of the family but can also be concerned with society in general (Chua et al., 1999).

No business vision is cast in stone. As (Chua et al., 1999) point out a business that changes its vision does not cease to be a family business. However there are two conditions that must be adhered to: (1) the change must emanate from by the family itself; and (2) the new vision for the business must reflect what the family wants it to be in the future.

Importantly Chua et al. (1999) point out that there does not have to be consensus on the new vision. In fact they argue that it does not even need to be supported by the majority of the members of the family. Realistically, a degree of opposition can be expected. What is important, however, is 
that those who initiate the change in vision must be able to implement it (Chua et al., 1999).

A shared vision provides a common framework on which to base managerial decision-making and to judge the relevance of issues. Two benefits that emanate from a shared vision are that opportunism is reduced and the sharing of information among decision-makers is enhanced (Dyer \& Singh, 1998). Also, a shared, vision-based understanding of roles and related tasks promote internal role specialisation (Ring \& Van de Ven, 1994) which improves the quality of information that different stakeholders make available for decision processes.

Ensuring commitment to a common, agreed-upon strategic direction is often difficult to achieve in many organisations because strategic decision processes are frequently characterised by conflict (Dooley, 1992). A shared vision in an organization is important because it clarifies the role interactions among stakeholders (Ring \& Van de Ven, 1994) and promotes coherence in their expectations. A shared vision also focuses stakeholders' opinions on organisational goals. A further benefit of a commonly-shared vision among stakeholders is a reduction in opportunistic behaviour and it develops social norms which reinforces commitment to jointly agreed-upon decisions (Uzzi, 1996). In a family business, a shared vision represents family members' collective ideas about the future of the business. This vision includes aspects such as the business domains in which the business wishes to compete, the growth rates it sees as desirable and its financial performance targets. This common vision is typically shaped by frequent interactions among family members. During these family get-togethers common beliefs and norms are developed (Nahapiet \& Ghoshal, 1998; Habbershon \& Astrachan, 1997).

Thus it is therefore hypothesised that:

$\mathrm{H}^{4}$ : There is a positive relationship between shared vision and perceived good governance.

\section{Ethnic entrepreneurial growth and good governance}

The next aspect this study investigated is the effect which ethnic entrepreneurial growth may have on good governance. Davidsson, Delmar and Wiklund, (2002) indicated that "if it were accepted that entrepreneurship is (sometimes) growth, the opposite must also be true: growth is (sometimes) entrepreneurship". Davidsson (1989:7) expressed it as follows: "Is growth entrepreneurship?" The answer to that question is contingent on the extent to which the manager is free to choose. If economic behaviour is discretionary, pursuing continued development of the firm is the more entrepreneurial choice when refraining from doing so constitutes another feasible alternative. In fact, business growth may perhaps best be conceived of as a collective term for several rather different phenomena, requiring separate methods of inquiry as well as separate theoretical explanations (Davidsson \& Wiklund, 2000; Delmar, 1997; Davidsson \& Delmar, 1998).

It may thus be advisable for research under this paradigm to include the concept of "emergence" or "creation" or what other researchers might call "early growth". The starting point in terms of time and size would thus determine whether or not "growth is entrepreneurship" (Davidsson et al., 2002). For proponents of the view that "entrepreneurship is new economic activity', form of growth is important. Although exceptions exist (e.g. Amit, Livnat, \& Zarowin, 1989; Penrose, 1959), the growth literature surprisingly rarely shows an interest in how or in which form businesses expand. Examples of growth trajectories and their causes can be found in the literature dealing with related topics such as mergers or acquisitions (Chatterjee \& Wernerfelt, 1991; Hoskisson, Johnson \& Moesel, 1994; Markides, 1995) or innovation and technological change (Tushman \& Anderson, 1986).

Markides and Williamson (1996) adopt a resource-based view, and suggest that acquisitions or mergers are used in order to acquire and exploit resources or assets owned by other companies. This tactic ensures that the same resources are unavailable to its rivals at a competitive cost. Penrose (1959) suggested that businesses that exhibit organic growth have the ability to detect emerging expansion opportunities, and to recombine existing resources in new ways, so as to take advantage of these opportunities. Penrose (1959) argues that "entrepreneurial resources" (or "entrepreneurial capability") are crucial for organic growth.

Organic growth is a different process. Barney (1988) argues that the reason organisations choose to grow through acquisitions is often the availability of excessive cash resources. This would suggest that the business's acquisition growth is determined by the size of its resource pool, rather than by its determination to develop new economic activities (Davidsson et al., 2002). Davidsson et al., (2002) also argue that when a business grows as a consequence of adding new activities, researchers have a case of entrepreneurship manifested as growth. One can argue that this type of organic growth could justifiably be regarded as entrepreneurship, while growth through acquisition could usually not.

Davidsson et al. (2002) have argued that it would be advisable to include what other researchers might call "early growth" into the operationalisation of "organisational creation". When entrepreneurship is viewed as new economic activity, it is reasonable to assume that growth of business represents entrepreneurship when the growth is achieved organically, whereas growth through acquisition does not normally represent entrepreneurship. As empirical results suggest that young and small businesses grow organically, whereas old and large businesses grow through acquisition, there is, in practice, considerable overlap between the two perspectives as concerns when "growth is entrepreneurship" appears to be the reasonable assumption (Davidsson et al., 2002).

Niche ethnic entrepreneurial concentration provides jobs for family members and other relatives. As the family becomes established economically, it invites other family members to join. The new ethnic entrepreneurial migrants begin work in the ethnic enterprise, but when they are later established economically, they invite other family members to join. Poutziouris et al., (1997) believe that entrepreneurial 
survivors face the challenge of ensuring the development of both the family business and the general business system, to sustain survival and growth of the family business into the next generations. The main strategic concern of family business growth is to ensure that the process of growth is both supported and controlled by the structures and processes of the business. Growth can take a variety of forms: exploitation of scale economics by plant expansion, modernisation of the technological base, diversification, and consolidation via merger or by other less formal modes of strategic alliance. A central stimulus factor for a successful growth strategy is the acceptance of the need for professionalisation of commercial practice, as the business develops from its previous family-oriented culture (Poutziouris et al., 1997).

It is therefore hypothesised that:

$\mathrm{H}^{5}$ : There is a positive relationship between ethnic entrepreneurial growth and perceived good governance.

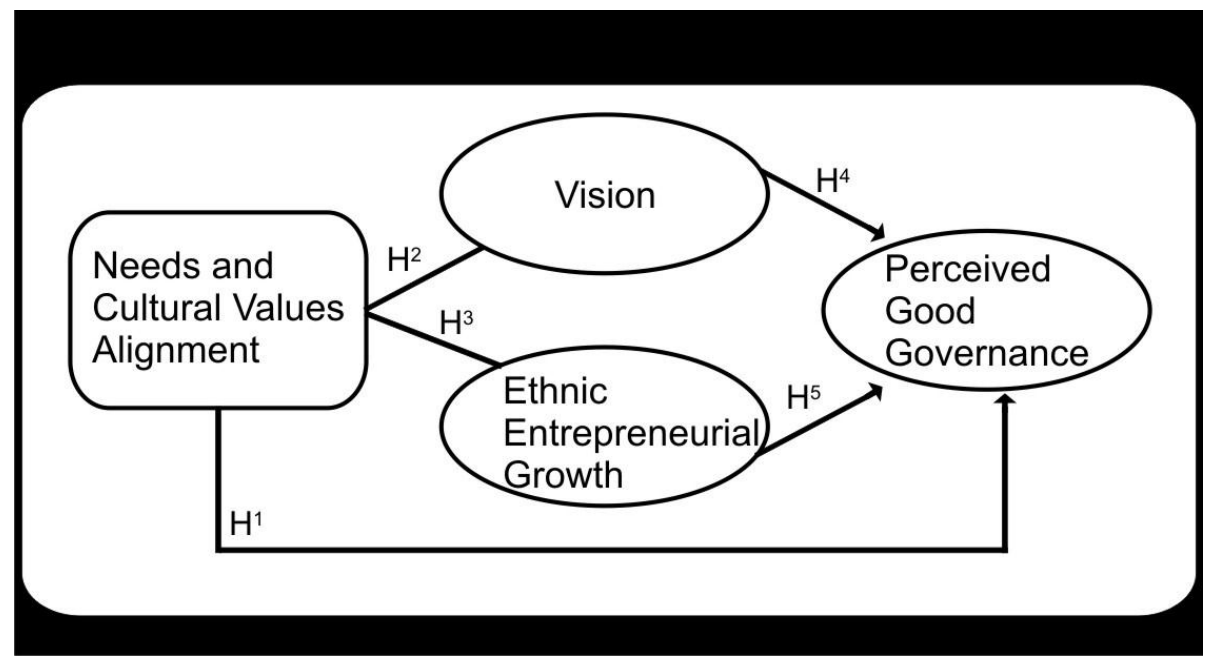

Figure 1: Hypothesised relationships

In this study the proposed theoretical model depicted in Figure 1 was empirically tested among respondents from Greek family businesses in South Africa.

\section{The dependent variable: Perceived good governance}

A definition of perceived good governance in family businesses should provide for two components, namely the good governance of the business and good governance within the family (Neubauer \& Lank, 1998). Various factors influence perceived good governance from a business perspective. These factors can broadly be categorised into factors pertaining to the influence of the founder/current owner(s) on governance; the influence of the family on governance; and the influence of the board of directors on governance.

Perceived good governance for South African Greek family businesses (the dependent variable in this study) is defined as the extent to which various stakeholders in the governance processes are actively involved in the family business, and monitoring of both the family and business systems ensuring that it is adequately attending to the myriad of issues associated with entrepreneurial leadership and ownership, cultivating and honouring the human needs of family members; subjecting to review the family governance model if changes are required; establishing a framework in which a sound governance model can work; maintaining certain values required to execute a good family governance model and finally, enforcing the stability, growth, and success of the family business.

\section{Methodology}

\section{Measuring instrument}

The measuring instrument used in this study consisted of items which have been confirmed as reliable and valid in previous studies. When published items were not available, self-developed items were used. All questionnaire items were linked to 7-point Likert-type scale with strongly agree scored as 7 and strongly disagree scored as 1 .

\section{Operationalisation of dependent and independent variable}

\section{Perceived good governance}

Perceived good governance in this study was operationalised as the specification of clear governance responsibilities, properly regulated governance issues, control measures, clear governance rules, business risks, sustainability planning, systems to ensure legal compliance and lastly, enabling of adequate accountability to all the stakeholders.

A nine-item scale was developed to measure perceived good governance. These items were mainly self-constructed, based on the work of Neubauer and Lank (1998), Martin (2001), Davis (2001), Lansberg (1999), Ward (1997) and Lansberg and Astrachan (1994). 


\section{Needs alignment}

Venter (2003) used four items in her study to measure needs alignment, operationalised as whether it is exciting, challenging, and rewarding to work in the family business; whether the opportunity exists to exercise influence and gain personal growth in the family business; and whether career needs and interests are closely aligned with opportunities in the business. In the present study, an eight-item scale was developed to measure needs alignment, which were the four items used by Venter (2003) and a combination based on the work of Neubauer and Lank (1998), Kaye (1996), Muske (2002) and Shen and Corella (2002).

\section{Cultural values alignment}

In the present study, cultural values alignment in the family business context is defined as the alignment of family cultural values with those of the family business concerned.

A four-item scale was constructed which was based on the theory of Hofstede (2001). Items included refer to the existence of cultural values and cultural beliefs, the compatibility of the values, and the compatibility of the customs within the family businesses concerned.

\section{Shared vision}

In this study, it is argued that a shared vision promotes coherence in stakeholders' expectations and opinions of the family business' goals. Established role interactions and a shared vision reduce the threat of opportunistic behaviour, and help establish a social norm of reciprocity, which reinforces good governance commitments or faintly agreed decisions and directives. In a family business, a shared vision involves family members' collective ideas about the future of the business, including desired business domains, desired growth rates, and financial performance. Mustakallio and Autio (2001) measured shared vision amongst family members using a three-item scale. This included asking whether family members shared the same vision about the family business; whether family members were committed to jointly agreed goals; and whether family members agreed about the long-term development objectives of the family business. A Cronbach alpha of 0.77 was reported by these authors for this construct.

A five-item scale was constructed for use in the present study based on the work of Uzzi (1996), Chua et al. (1999), Dooley (1992), Habbershon and Astrachan (1997) and the study done by Mustakalio and Autio (2001).

\section{Ethnic entrepreneurial growth}

An eight-item scale was developed based on the work of Davidson et al. (2002), Maas (1999), Brockhaus (1982), Penrose (1959), Venkataraman (1997), and informal interviews with South African Greek family business entrepreneurs. Ethnic entrepreneurial growth was operationalised as the consideration of future international expansion, the generation of money as an important goal, and the fostering of an entrepreneurial culture within the family business concerned.

\section{Statistical procedures}

In order to identify the unique factors in the data, an exploratory factor analysis was conducted (subject to the assessment of the factor analysability of the correlation matrix by considering the KMO statistic and Bartlett's test of sphiricity). In both cases these indices indicated that the data were factor analysable. In this way, the discriminant validity of the measuring instrument could be assessed. The computer programme BMDP4M was used for this purpose. To confirm the reliability of the instrument used, each factor's Cronbach alpha coefficient was calculated. Structural equation modelling was used to measure the relationships amongst the set of variables (independent variables) identified as influencing good governance (the dependent variables) in Greek family businesses in South Africa.

\section{The sample}

The questionnaire was pre-tested amongst 21 respondents of South African Greek family businesses in order to ensure ease of understanding and a suitable length of time for completion. Minor alterations were made to the final questionnaire as a result before national distribution.

From the total sample of 331,242 respondents $(73,1 \%)$ were males and $89(26,9 \%)$ were females. As expected from the majority of the South African Greek sample, the majority of $177(53,5 \%)$ were from Aegean Greek origin.

\section{The empirical results}

\section{Discriminate and construct validity assessment and reliability assessment}

The quartimax rotated factor matrix for the independent variables is reported in Tables 1 and 2 and for the dependent variable in Table 3. In an attempt to assess the reliability of the measuring instrument used to measure the latent variables in the theoretical model, Cronbach-alpha coefficients were calculated (Table 4).

Table 1: Antecedent variables: Needs alignment and cultural values

\begin{tabular}{c|c|c|c}
\hline & Factor 1 & & Factor 2 \\
\hline Items & Needs Alignment & & Cultural Values \\
\hline NA 5 & 0,752 & CVA 3 & 0,898 \\
\hline NA 4 & 0,689 & CVA 4 & 0,778 \\
\hline NA 8 & 0,575 & CVA 5 & 0,684 \\
\hline NA 6 & 0,467 & CVA 2 & 0,687 \\
\hline & & CVA 1 & 0,545 \\
\hline
\end{tabular}

Table 2: Intervening variables: Entrepreneurial growth and vision

\begin{tabular}{c|c|c|c}
\hline & Factor 1 & & Factor 2 \\
\hline Items & Entrepreneurial Growth & & Vision \\
\hline ENT 7 & 0,158 & TRU 3 & 0,793 \\
\hline ENT 6 & 0,705 & COM 4 & 0,648 \\
\hline ENT 8 & 0,581 & ENTG 1 & 0,490 \\
\hline
\end{tabular}


Table 3: Quartimax rotated factor matrix: The dependent variables

\begin{tabular}{l|c|c|c}
\hline Items & Factor 1 & Factor 2 & Factor 3 \\
\hline GG8 & $\begin{array}{c}\text { Stakeholders } \\
\text { Interest }\end{array}$ & $\begin{array}{c}\text { Internal } \\
\text { Environment }\end{array}$ & Risk Control \\
\hline GG9 & $\mathbf{0 , 8 7 7}$ & $-0,064$ & $-0,009$ \\
\hline GG4 & $\mathbf{0 , 7 5 3}$ & $-0,043$ & 0,061 \\
\hline GG1 & $\mathbf{0 , 4 3 9}$ & 0,201 & $-0,021$ \\
\hline GG2 & $-0,032$ & $\mathbf{0 , 8 3 0}$ & $-0,057$ \\
\hline GG3 & $-0,014$ & $\mathbf{0 , 6 0 1}$ & 0,273 \\
\hline GG7 & 0,166 & $\mathbf{0 , 5 5 5}$ & 0,110 \\
\hline GG6 & $-0,058$ & $-0,014$ & $\mathbf{0 , 8 9 4}$ \\
\hline GG5 & 0,054 & 0,024 & $\mathbf{0 , 4 9 5}$ \\
\hline
\end{tabular}

Table 4: Internal reliablity assessment

\begin{tabular}{l|c}
\hline & Cronbach Alpha Values \\
\hline Needs Alignment & 0,783 \\
\hline Cultural Values Alignment & 0,862 \\
\hline Vision & 0,760 \\
\hline Entrepreneurial Growth & 0,691 \\
\hline Risk control & 0,677 \\
\hline Stakeholders' Interest & 0,744 \\
\hline Internal Regulatory Control & 0,794 \\
\hline
\end{tabular}

Table 1 shows that that the latent variable 'Needs and Cultural values Alignment' split into two. Four of the eight items expected to measure the construct Needs Alignment loaded to a significant extent on one factor, namely (NA4, NA5, NA6, NA8). The other four items were deleted due to poor discriminant validity. The scale returned a Cronbach alpha of 0,783 .

Table 1 also shows that the items (CVA1-CVA5) used to measure the construct Cultural Values Alignment all loaded together in the factor analysis. This factor has a Cronbachalpha coefficient of 0,862 .

Table 2 indicates that a new factor (not initially modelled) emerged from the exploratory factor analysis consisting of three items expected to measure Trust (TRU3), Communication (COM4) and Ethnic Entrepreneurial Growth (ENTG1) respectively. Since these three items measure the desired state as it is visioned to be by the founder/current owner in terms of internal cohesion, it was decided to name this factor Vision (rather than Shared Vision as originally operationalised). The Vision factor returned a Cronbach alpha coefficient of 0,76 .

Eight items were included in the original measuring instrument to measure the construct Ethnic Entrepreneurial Growth. Three items (ENTG6, ENTG7 and ENTG8) loaded together on this factor. The Ethnic Entrepreneurial Growth factor returned a Cronbach alpha coefficient of 0,691.

The items used to measure the dependent variable perceived Good Corporate Governance were similarly subjected to an exploratory factor analysis. Table 3 shows the construct consists of three underlying sub-dimensions which were respectively labelled: Risk control, Stakeholders' interest and Regulatory Environment. It thus appears that if family businesses are able to ensure and protect the interests of all stakeholders, have internal governance rules and responsibilities clearly spelled out, and are able to manage risk to ensure the sustainability of the family business, it would be appropriate to describe them as adhering to good governance practices.

From the original questionnaire, three items (GG4, GG8 and GG9) loaded on a factor named Stakeholders' Interest. All three items, namely adequate accountability towards the stakeholders, the ensuring of legal compliance, and very little conflict in the business, are all direct elements of looking after the Stakeholders' Interests by the respondents of this study. Stakeholders' Interest returned a Cronbachalpha coefficient of 0,744 .

Three items (GG1, GG2 and GG3) loaded on a factor named Internal Regulatory Environment. The items measuring clearly specified governance responsibilities, clear governance rules, and the proper regulation of family business governance, were all interpreted by the respondents as adhering to the conditions stipulated by the Internal Regulatory Environment to ensure good governance. This factor has a Cronbach alpha value of 0.794 .

Three items (GG5, GG6 and GG7) loaded together on a factor named Risk Control. The respondents of this study interpreted that business with appropriate control measures, well-managed business risks, and proper planning for sustainability are all seen as measures for well-governed Risk Control. The Cronbach alpha coefficient of this factor was 0,677 .

Despite the fact that the exploratory factor analysis revealed three underlying sub-dimensions, the latent variable 'perceived good governance' was treated as unidimensional. Because the latent variable 'Needs and Cultural values Alignment' split in two, $\mathrm{H} 1$ had to be reformulated as $\mathrm{H} 1 \mathrm{a}$ and $\mathrm{H} 1 \mathrm{~b}$.

$\mathrm{H}^{1 \mathrm{a}}$ : There is a positive relationship between needs alignment and perceived good governance.

$\mathrm{H}^{\mathrm{lb}}$ : There is a positive relationship between cultural values alignment and perceived good governance.

$\mathrm{H}^{2}$ : There is a positive relationship between needs alignment and vision.

$\mathrm{H}^{3}$ : There is a positive relationship between cultural values alignment and ethnic entrepreneurial growth.

$\mathrm{H}^{4}$ : There is a positive relationship between a vision of cohesion and perceived good governance.

$\mathrm{H}^{5}$ : There is a positive relationship between ethnic entrepreneurial growth and perceived good governance.

All the remaining items reported in both Tables 1 and 2 reveal statistically significant loading for all items and each item loads to a significant extent on only one factor, suggesting a high level of discriminant validity. The results reported in Table 1,2 and 3 necessitated a revision of the original theoretical model. 
Once the discriminant and construct validity of the instruments and the resultant data had been assessed, the next step was to assess the measurement model by means of a confirmatory factor analysis (CFA). An inspection of the distributional properties of the data revealed that the assumption of multivariate normality does not hold true for this data set. As a result, Robust Maximum Likelihood (RML) estimation was used as recommended by Jöreskog and Sörbom (2003).

\section{The structural model}

The Robust Maximum Likelihood estimation results of the structural model are reported in Figure 3. The various model fit indices of the structural model are reported in Table 5. The Root Mean Square Error of Approximation (RMSEA) of 0,077 suggests an acceptable fit of the model to the data (Hair, Anderson, Tatham \& Black, 1998: 656; Grimm \& Yarnold, 2000: 271). It must be kept in mind however, that the objective of this study was not to achieve a good fitting model but rather to assess the relationships among the different latent variables.

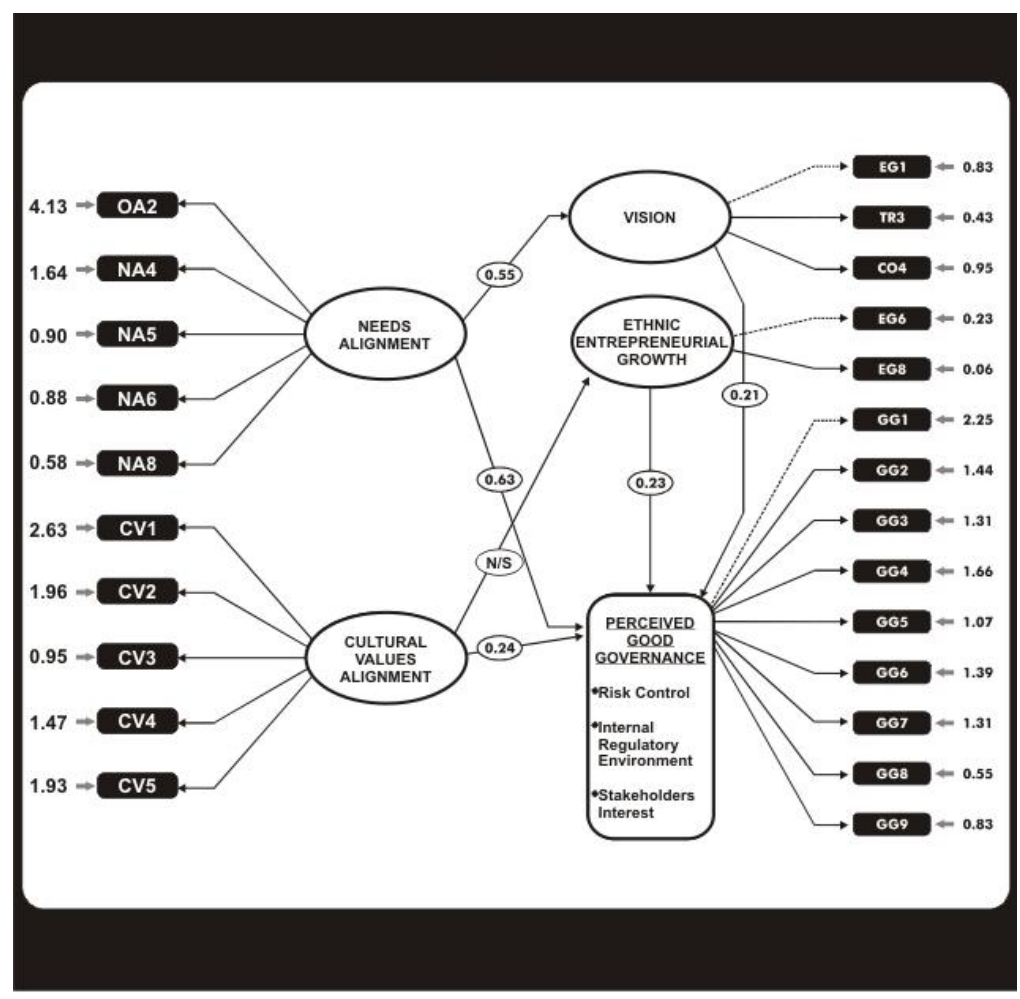

Figure 2: Structural model

Table 5: Goodness-of-fit indices

\begin{tabular}{l|c}
\hline \multicolumn{1}{c|}{ Index } & Value \\
\hline Degrees of freedom $(d f)$ & 245 \\
\hline Chi-square $\left(\chi^{2}\right)$ & 1082,5 \\
\hline Root mean square residual (RMR) & 0,210 \\
\hline Root mean square error of approximation (RMSEA) & 0,077 \\
\hline
\end{tabular}

Figure 2 shows that there is a positive relationship (point estimate $=0,63, t=6,24, p<0,001$ ) between needs alignment and perceived good governance (Hypothesis $\mathrm{H}^{1 \mathrm{a}}$ ). In other words, the better the needs of the Greek family member are aligned with opportunities offered by the family business, the better the chances will be that good governance will prevail. Hypothesis $\mathrm{H}^{1 \mathrm{a}}$ can thus not be rejected.

Figure 2 indicates that there is a positive relationship between cultural values alignment and perceived good governance (Hypothesis $\mathrm{H}^{1 \mathrm{~b}}$ ). According to the respondents of this study, the more cultural values alignment takes place, the more effective risk control, the internal regulatory environment and taking care of the stakeholders' interests will be for South African Greek family businesses. This study's findings concur with those reported by previous studies, in the sense that generational family businesses, for example, typically develop traditions, cultural values, and customs that are reflected in their administration, business strategies, and governance performance (Ward \& Dolan, 1998; Gopalkrishnan \& Shapiro, 2000; Corbetta, 1995). $\mathrm{H}^{\mathrm{lb}}$ could thus not be rejected.

Figure 2 also demonstrates that the needs alignment of the Greek family member has a significant and positive influence (point estimate $=0,55, \mathrm{t}=6,18, \mathrm{p}<0,001$ ) on the vision of the business $\left(\right.$ Hypothesis $\mathrm{H}^{2}$ ). In other words, the more the needs alignment of the family member is in line with the business, the more positively it will reflect in the vision of the business. Hypothesis $\mathrm{H}^{2}$ can thus not be rejected.

The empirical results also revealed that cultural values alignment does not have a significant influence on ethnic entrepreneurial growth (point estimate $=-0,07, \mathrm{t}=-0,92, \mathrm{p}>$ $0,001)$. Hypothesis $\mathrm{H}^{3}$ is thus rejected.

Hypothesis 5 suggested that there is a significant and positive relationship between vision (of the manager/founder) and 
perceived good governance. This hypothesised relation has been empirically confirmed (point estimate $=0,21, \mathrm{t}=3,22, \mathrm{p}$ $<0,001)$. This finding suggests that the more the Greek family member identifies with the vision of the business, the more effective risk control, the internal regulatory environment and looking after the stakeholders' interests will be. Hypothesis $\mathrm{H}^{4}$ could thus not be rejected.

According to Figure 2 there is a positive relationship (point estimate $=0,23, \mathrm{t}=4,29, \mathrm{p}<0,001$ ) between ethnic entrepreneurial growth and perceived good governance as suggested by $\mathrm{H}^{5}$. In other words, the higher the ethnic entrepreneurial growth of the Greek family business, the more positively it will reflect on risk control, the internal regulatory environment and taking care of the stakeholders' interests to ensure good governance. Hypothesis $\mathrm{H}^{5}$ could thus not be rejected.

These findings are in line with previous research findings. Ethnic enterprises provide jobs for family members and other relatives. The new migrants begin work in the ethnic enterprise, but when they are established economically, they invite other family members to join (Mantzaris, 2000; Poutziouris et al., 1997). Pourtziouris et al., (1997) also found that entrepreneurial survivors faced the challenge of ensuring the development of both the family business and the general governance system to sustain survival and growth of the family business into the next generation. The main strategic concern of ethnic entrepreneurial growth is both supported and controlled by the governance structures and processes of the business. Poutziouris et al., (1997) also found that the central stimulus factor for a successful entrepreneurial growth strategy is the acceptance of the need for professionalisation of commercial practice as the business develops from its previous family-orientated culture.

The literature findings suggests that the family business is a business governed and/or managed with the intention of shaping and pursuing the vision of the business held, by the dominant coalition and controlled by the members in such a manner that it is potentially sustainable across generations of the family or families (Dyer \& Singh, 1998; Handler, 1989).

\section{Conclusions and recommendations}

This study confirmed the relationship between the needs alignment of the family members and the vision of the South African Greek family business have a significant influence on the effort to ensure good governance. A South African Greek in a family business is often under pressure by the founder/current owner to follow the vision that is portrayed for both the family and the business. As a result, the rest of the family members are expected firstly to bring their needs in line with the vision of the business and that of the family. This process seems to happen over a period of time and over time becomes second nature to them.

The literature also revealed that the quality of a family business member's personal life experience is in part a function of his ability to meet the developmental needs of the business. The South African Greek family business member sees the personal needs alignment in general as the degree to which an individual's needs are properly aligned with opportunities available in the context of the family business. In other words, if there is a need for a specific skill within the family business the individual will be required to train/study in order to fulfil that particular need. This may require time, but most often depending on the business needs, training to become, for instance, a chartered accountant, a lawyer or a marketer, is undertaken on a parttime basis. In order to make informed choices about their future, the potential heirs need to assess their career goals, their family relationships, and their possible shareholding in the family business. The degree to which the South African Greek family business owner assists the rest of the family members in order to promote the family business, can be seen as a good indication of the ease of authority that is transferred in the best interest of the family business and the next generations.

Venter (2003) is of the opinion that "the next generation family member will have a positive succession experience if the member has achieved fulfilment of three types of needs, namely career interest needs, psychosocial needs, and lifestage needs." South African Greeks believe that if the interests or competencies of their daughters do not fit the needs of the business, the family should provide them with a fair share of support to pursue other career opportunities. Failing this, they would have to fulfil a role in the prospective spouse's family business. Lansberg (1988)has shown that if parents appoint a family member purely on the basis of family relationships, and the family member does not possess the necessary skills, interest or dedication to succeed, norms of equality, rather than equity, are applied. For instance in the failure to acknowledge differences or inequalities among one's children. It also emerged during interviews, (particularly with those members of cousinconsortium family businesses), that the leadership capabilities of the next generation are important, and that the possible heir might need time to grow in stature. It is believed that a son (or daughter) should never be awarded an opportunity as a controlling partner within the business if he (or she) does not yet possess the skills, training, or dedication to succeed.

It has become apparent that the more personal needs and career interests are aligned with the opportunities offered by the family business, the better the chances are that good governance will prevail in the family business. Thus, as established in this study, the needs alignment has a direct influence on perceived good governance in South African Greek family businesses. The empirical results have shown that the vision for the business is an important determinant of ethnic entrepreneurial growth for the South African Greek family business to ensure good governance. There was the perception among the respondents of this study that following the vision of the founder/current owner would contribute to the entrepreneurial growth of the family business.

According to the literature, a shared vision promotes coherence in the stakeholders' expectations and opinions regarding organisational goals. This, in turn, promotes cooperative behaviour through clarified role interactions. It has been advocated by some South African Greek family business members that a family council can provide the 
structure to implement and direct the shared vision through a "code of understanding" as part of their business plan. In a family business, a shared vision is said to involve the family members' collective idea about the future of the business, including desired business domains, desired growth rates, and financial performance. Frequent interactions enable family business members to forge a shared view of the goals of the family; family gatherings and meetings contribute towards the expression of shared beliefs.

The empirical results also proved that there is a positive, direct and significant relationship between cultural values alignment and perceived good governance. This relationship suggests that the more the South African Greek family business members align their cultural values, beliefs and customs with the business, the more perceived good governance will be influenced. The development of fair procedures and rules of good governance ensure that the emotion-based culture family system submits to a professionally orientated family business approach, and that potential conflict between family culture values and the values and goals of the family business is appropriately aligned. After all, perceived good governance should provide for good governance of the business and good governance within the family.

The main strategic concern of family business's entrepreneurial growth is to ensure that the process of growth is both supported and controlled by the governance structures and processes of the business. In support of this concern, the South African Greek family businesses indicated the importance of risk control, adhering to the conditions of the internal regulatory environment, and looking after the stakeholders' interests as important determinants when considering the factors of entrepreneurial growth for the family businesses concerned.

Entrepreneurial growth takes a variety of forms: exploitations of scale economics by plant expansions, modernisation of the technological base, diversification, and consolidation via mergers and acquisitions, or by other less formal modes of strategic alliance. Poutziouris et al., (1997) mentioned that a central stimulus for a successful entrepreneurial growth strategy is the acceptance of the need for professionalisation of commercial practice, as the business develops from its previous family-orientated culture.

\section{Summary, limitations and recommendations for future research}

This is one of the few studies that empirically assesses an integrated model of cultural-related factors, especially culture related factors and its impact on good governance. The areas covered by this empirical study remained unexplored until now. The findings reported here provide the foundation and introduction, thereby acting as a basis of comparison for future research in the fields of perceived good governance for family businesses, international Greek family businesses, and in particular family businesses of a cross-cultural group.
The research was designed to allow for a better understanding of good governance for South African Greek family businesses. While the quantitative approach facilitated in-depth exploration, it also required limiting the research scope and the sample. It was necessary to choose a usable sample, which was not a limitation in itself, but there were potential limitations associated with the method chosen for this study.

In summary, this study has provided an entrance to an entire area of research, not only into international and South African Greek family businesses, but into family businesses where ethnic entrepreneurs exist. There are many cultures where it is customary that people are sent to foreign cultures to work for extended periods of time. Clearly, for the family businesses from these cultures, there may be implications in terms of governance experiences. The cross-cultural aspect of family business governance must now be considered when conducting such research, as more and more emphasis is placed on good governance for all businesses concerned.

\section{References}

Adair, W., Brett, J., Lempereur, A., Okumura, T., Tinsley, C. \& Lytle, A. 1998. Culture and negotiation strategy. Evanston, IL: Dispute Resolution Research Center, NorthWestern University.

Adendorff, C. M. 2004. 'The development of a cultural family business model of good governance for Greek family businesses in South Africa'. Unpublished doctoral thesis, Rhodes University, Grahamstown.

Adendorff, C., Boshoff, C., Court, P. \& Radloff, S. 2005. 'The impact of planning on good governance practices in South African Greek family businesses', Management Dynamics, 14(4):34-45.

Adendorff, C., Boshoff, C. \& Venter, E., 2008. 'The impact of family harmony on good governance practices in South Africa', Management Dynamics, 19(1): 27-47.

Adendorff, C. \& Boshoff, C. 2009. 'The management of good governance in Greek family businesses in South Africa'. Paper presented at the International Business School Conference, Zanzibaar, 16-17 September, 2009.

Aldefer, C.P. 1988. 'Understanding and consulting to family business boards', Family Business Review, 1(13): 249-261.

Amit, R., Livnat, J. \& Zarowin, P. 1989. 'The mode of corporate diversification: Internal ventures versus acquisitions', Managerial and Decision Economics, 10: 89100.

Astrachan, J.H\& Astrachan, B.M. 1993. 'Family businesses: The challenges and opportunities of interpersonal collaboration'. In Aronoff, C.E., Astrachan, B.M. \&Ward, J.L. (eds.)Family Business Sourcebook 2, Marietta Business Owner Resources, 535-546.

Bjurren, P. \& Sund, L. 2000. 'Organization of successions of small and medium sized enterprises within the family'. In 
Proceedings of the International Council for Small Business, 45th World Conference, Brisbane, Australia, 7 10 June: 1-17. (CD Rom).

Chatterjee, S.\& Wernerfelt, B. 1991. 'The link between resources and type of diversification: Theory and evidence', Strategic Management Journal. 12 (January): 33-48.

Chua, J.H., Chrisman, J.J.\& Sharma, P. 1999. 'Defining the family business by behaviour', Entrepreneurship, Theory and Practice, 23(4): $19-39$.

Connolly, G. \& Jay, C. 1996. The private world of family business. Pearson Professional. (Australia) Pty Ltd. published and distributed by Woodslane, NSW, Australia.

Corbetta, G. 1995. Le imprese familiari. Milano: Egea.

Cox, T.H. \& Blake, S. 1991. 'Managing cultural diversity: Implications for organisational competitiveness', Academy of Management Executive, 5: 45-56.

Craig, J. \& Lindsay, N.J. 2002. 'Incorporating the family dynamic into the entrepreneurship process', Journal of Small businesses and Enterprise Development. 9(4): 416430 .

Daily, C.M. \& Dollinger, M.J. 1991. 'Family firms are different', Review of Business, 13(1): 3-5.

Davidsson, P. 1989.Continued entrepreneurship and small firm growth. Stockholm: Stockholm School of Economics, Centre for Media and Economic Psychology.

Davidsson, P. \& Delmar, F. 1998. 'Zur Schaffung von Arbeitsplätzen nach Firmengrösse und-Alter', Zeitschrift für Klein- und Mittelunternehmen, 46: 219-233.

Davidsson, P., Lindmark, L. \& Olofsson, C. 1998. 'The extent of overestimation of small firm job creation: An empirical examination of the 'regression bias', 'Small Business Economics, 10: 87-100.

Davidsson, P. \& Wiklund, J. 2000. 'Conceptual and empirical challenges in the study of firm growth'. In Sexton, D.L.\& Landström, H. (Eds.). The Blackwell handbook of entrepreneurship. Malden, MA: Blackwell Publishers Ltd. Pp. 26-44.

Davidsson, P., Delmar, F. \& Wiklund, J. 2002. 'Entrepreneurship as growth: growth as entrepreneurship'. In Hitt, M.A., Ireland, R.D., Camp, S.M. \& Sexton, D.L. (Eds.). Strategic entrepreneurship: Creating a new integrated mindset. Oxford, UK: Blackwell.

Davis, J. 2001. 'HBS working knowledge. Family matters: Governing the family run business(Part one)'. Harvard Business School. [online] URL:

http://hbswk.hbs.edu/pubitem.jhtml?id=2469andsid=0andt =family

Delmar, F. 1997. 'Measuring growth: methodological considerations and empirical results'. In Donckels, R. \&
Miettinen, A. (Eds.). Entrepreneurship and SME research: On its way to the next millennium. Aldershot, VA: Avebury. pp. $190-216$.

De Mooij, M. 1997. Global marketing and advertising. Understanding cultural paradoxes. Thousand Oaks: Sage.

Dimitriades, E. 2004. 'Greek family businesses'. Conference paper presented at the Scandinavian Academy of Management and International Federation of Scholarly Associations of Management World Congress, 5-7 July 2004, Gothenburg, Sweden.

Dooley, M.P. 1992. 'Two models of corporate governance: Analysis of the American Law Institute's principles of corporate governance', 47 Business Lawyer. October: 503542.

Dyer, W.G. 1986. Cultural change in family firms: Anticipating and family transitions. San Francisco: JosseyBass.

Dyer, W.G. 1994. 'Potential contributions of organizational behaviour to the study of family owned businesses', Family Business Review, 7(2): 109-131.

Dyer, G.W. \& Singh, H. 1998. 'The relational view: Cooperative strategy and sources of inter-organisational competitive strategy', Academy of Management Review, 23(4): 660-679.

Gartner, W.B. 1988. 'Who is the entrepreneur? Is the wrong question', American Journal of Small Businesses, 12:11-32.

Gersick, K.E., Davis, J.A., McCollom-Hampton, M.M. \& Lansberg, I. 1997. 'Choosing the right ownership structure'. In Fischetti, M. The family business succession handbook. Philadelphis: Family Business Publishing, pp. 7-8.

Goldberg, S.D. 1991. 'Factors which impact effective succession in family-owned businesses: An empirical investigation'. Unpublished doctoral thesis, University of Massachusetts, Massachusetts.

Gopalakrishnan, R.I. \& Shapiro, J.M. 2000. 'Cultural factors and consequences in entrepreneurial behaviour and business strategies', Review of Business, 12(1): 3-9.

Grimm, L.G. \& Yarnold, P.R. 2000. Reading and understanding more multivariate statistics. Washington DC, USA: America Psychological Association.

Habbershon, T.G. \& Astrachan, J.H. 1997. 'Perceptions are reality. How family meetings lead to collective action', Family Business Review, 10(1): 37-52.

Hair, J.F., Anderson, R.E., Tatham, R.L. \& Black, W.C. 2005.Multivariate data analysis. $5^{\text {th }}$ Edition. Upper Saddle River, New Jersey: Prentice-Hall.

Häkanson, H. 1982. International marketing and purchasing of industrial goods. New York: Wiley. 
Hampden-Turner, C.\& Trompenaars, F. 2000. Building cross-cultural competence: How to create wealth from conflicting values. Chichester: John Wiley.

Handler, W.C. 1989. 'Managing the family firm succession process: The next generation family member's experience.' Unpublished doctoral thesis, Boston University, Boston.

Hofstede, G. 2001. Culture's consequences: Comparing values, behaviours, institutions, and organisations across nations. London: Sage Publications.

Hoskisson, R.E., Johnson, R.A. \& Moesel, D. 1994. 'Corporate divestiture intensity in restructuring firms: Effects of governance, strategy, and performance', The Academy of Management Journal, 37(5): 1207-1251.

Hoy, F. \& Verser, T.G. 1994. 'Emerging business, emerging field: Entrepreneurship and the family firm', Entrepreneurship Theory and Practice, 19(1): 9-23.

Hume, S.A. 1991. 'An assessment of the risk of family business failure'. Unpublished doctoral thesis, Antioch University, New Hampshire.

IFERA (International Family Enterprise Research Academy). 2003. 'Family business review', Journal of the Family Firm Institute, 16(3): 235-240.

Jöreskog, K. \& Sörbom, D. 2003. Lisrel 8: User's Reference Guide. Chicago: Scientific Software International.

Kalantzis, M. \& Cope, B. 1992. Managing cultural diversity. Haymarket, N.S.W:NLLIA Centre for Workplace Communication and Culture.

Katz, J. \& Gartner, W.B. 1988. 'Properties of emerging organizations', Academy of Management Review, 13(3): 429-441.

Kaye, K. 1991. 'Penetrating the cycle of sustained conflict', Family Business Review, 4(1): 21-41.

Kaye, K. 1996. 'When the family business is a sickness', Family Business Review, 11(4): 347-368.

Institute of Directors of Southern Africa. 2002. King Report II. Johannesburg: Institute of Directors of Southern Africa.

King, R. 2001. (Ed.). The Mediterranean passage, migration and new cultural encounters in Southern Europe. Liverpool: Liverpool University Press.

Koliopoulos, J.S. \& Veremis, T.M. 2002. Greece: The modern sequel. London: Hurst and Company.

Lansberg, I.S. 1988. 'The succession conspiracy', Family Business Review. (Summer) 1(2). Reprinted in Aronoff, C.E., Astrachan, J.H., Ward, J.L., (Eds.). 1996. The family business sourcebook II. Georgia: Business Owner Resource, pp. $70-86$.
Lansberg, I. 1999. 'Independent directors in the middle', Family Business Review,4(Summer): 43-48.

Lansberg, I.S. \& Astrachan, J.H. 1994. 'Influences of family relationships on succession planning and successor training: The importance of mediating factors', Family Business Review,7(1): 39-59.

Maas, G. 1999. 'Family business in South Africa: A development model'. Paper presented at the Saesba Conference, July 30 - August 1 1999, Perth, Australia,pp.115 .

Mantzaris, E. A. 1978. 'The social structure and the process of assimilation of the Greek community in South Africa.' Unpublished M.Soc. Science thesis, Department of Sociology, University of Cape Town.

Mantzaris, E, A. 2000. 'A social history of the Greek community in South Africa'. Unpublished manuscript.

Markides, C. C. 1995. 'Diversification, refocusing and economic performance', Strategic Management Journal, 16: $101-118$.

Markides, C.C. \& Williamson, P.J. 1996. 'Corporate diversification and organizational structure: A resourcebased view', Academy of Management Journal 39(2): 340367.

Martin, H.F. 2001. 'Is family governance an oxymoron?', Family Business Review, 14(2): 91-96.

McCann, G., Hammon, G., Keyt, A. \& Fujiuchi, K. 2004. 'A view from afar: Rethinking the director's role in universitybased family business programs', Family Business Review, 17(3): 203.

McWhinney, W. 1988. 'Entrepreneurs, owners, and stewards: The conduct of a family business,' New Management, 6(1): 4-12.

Morgan, R.M. \& Hunt, S.D. 1994. 'The Commitment-trust theory of relationship marketing', Journal of Marketing. (July) 58: 20-38.

Muske, G. 2002. Family business research group report on 1997 National Family Business Survey and 2000 National Family Business Survey. Presentation at the Family Firm Institute Annual Conference, Dallas, Texas. February 2002.

Mustakallio, M. \& Autio, E. 2001. 'Effects of formal and social controls on strategic decision making in family firms'. Paper read at the 12th Annual World Conference, Rome.

Nahapiet, J. \& Ghoshal, S. 1998. 'Social capital, intellectual capital, and organizational advantage', Academy of Management Review. 23(2): 242 - 266.

Neubauer, F. \& Lank, A.G. 1998. The family business - its governance for sustainability. New York: Routledge. 
$\mathrm{Ng}, \mathrm{M}$. 1999. 'Unaccompanied minors and succession in overseas Chinese family businesses in Hong Kong'. Unpublished PHD Thesis, University of London, London.

Penrose, E.T. 1959. The theory of the growth of the firm. New York: Oxford University Press\& John Wiley.

Poutziouris, P., O' Sullivan, K. \& Nicolescu, L. 1997. 'The (re)generation of family business entrepreneurship in the Balkans', Family Business Review, 10(3): 239-262.

Ring, P.S. \& Van De Ven, A.H. 1994. 'Developmental processes of cooperative inter-organizational relationships', Academy of Management Review,19(1): 90 - 118.

Rogers, E.M. 1995. Diffusion of innovations. $4^{\text {th }}$ Edition. New York: Free Press.

Sharma, P.1997. 'Determinants of the satisfaction of the primary stakeholders with the succession process in family firms'. Unpublished doctoral thesis, University of Calgary, Canada.

Sharma, P., Chrisman, J.J. \& Chua, J.H. 1997. 'Strategic management of the family business: Past research and future challenges', Family Business Review, 10(1): 1-35.

Shen, W. \& Conella Jr., A.A. 2002. 'Revisiting the performance consequences of CEO succession: The impacts of successor type, post-succession senior executive turnover, and departing CEO tenure', The Academy of Management Journal, 45(4): 1195-2007.

Serrano, C. 2000. 'Family businesses in Mexico - A preliminary report', The Family Business Network Newsletter. (July/August), 27: 23.

Spiro, F. 2003. Personal communication. Tutor in the Greek language and Greek custom at the Greek Orthodox Church, Port Elizabeth.

Steier, L. 2001. 'Family firms, plural forms of governance, and the evolving role of trust', Family Business Review, 14(4): 353-367.

Triandis, H.C. 2000. 'Culture and conflict', International Journal of Psychology, 35(2): 145-152.

Tushman, M.L. \& Anderson, P. 1986. 'Technological discontinuties and organizational environments', Administrative Science Quarterly, 31: 439-65.

Uzzi, B. 1996. 'The sources and consequences of embeddedness for economic performance of organizations: The network effect', American Sociological Review. August, 61: 674-698.

Vaida, G. 2005. 'The peril of being unethical', Sunday Times Business Section, 12 June, pp.34.

Van der Merwe, S.P. 1999. 'Formal planning of family businesses in the Vaal Triangle'. Unpublished doctoral thesis, University of Potchefstroom for Christian Higher Education, Potchefstroom.

Venkataraman, S. 1997. 'The distinctive domain of entrepreneurial research: An editor's perspective'. In Katz, J. \& Brockhaus, R. (Eds.). Advances in entrepreneurship firm emergence and growth. Greenwich, CT: JAI Press, pp. 119- 138.

Venter, E. 2003. 'The succession process in small and medium-sized family businesses in South Africa'. Unpublished doctoral thesis, Nelson Mandela Metropolitan University, Port Elizabeth, South Africa.

Ward, J.L. 1997. 'Growing the family business: Special challenges and best practices', Family Business Review, 10(4): 323 - 337.

Ward, M. 1995. Greek assignments SOE 1943 - 1948. Athens: Lycabettus Press.

Ward, J.L. \& Dolan, C. 1998. 'Defining and describing family business ownership configurations', Family Business Review, 11(4): $305-310$.

Zabkar, V. \& Brencic, M.M. 2001. 'Values, trust, and commitment in business-to-business relationships: A comparison of two former Yugoslav markets', International Marketing Review, 21(2): 202 - 215.

Zimmerer, T.W. \& Scarborough, N.M. 2002. Essentials of entrepreneurship and small business management. $3^{\text {rd }}$ Edition. New Jersey: Prentice Hall. 